\title{
Immunomodulatory Activity of Biofield Energy Healing Based Herbomineral Formulation in Sprague Dawley Rats: Evidence for Humoral and Cell-Mediated Responses
}

\author{
Mahendra Kumar Trivedi ${ }^{1}$, Alice Branton ${ }^{1}$, Dahryn Trivedi ${ }^{1}$, Gopal Nayak ${ }^{1}$, Michael Peter Ellis ${ }^{1}$, \\ James Jeffery Peoples ${ }^{1}$, James Joseph Meuer ${ }^{1}$, Johanne Dodon ${ }^{1}$, John Lawrence Griffin ${ }^{1}$, \\ John Suzuki ${ }^{1}$, Joseph Michael Foty ${ }^{1}$, Judy Weber ${ }^{1}$, Julia Grace McCammon ${ }^{1}$, Karen Brynes Allen ${ }^{1}$, \\ Kathryn Regina Sweas $^{1}$, Lezley Jo-Anne Wright ${ }^{1}$, Lisa A. Knoll ${ }^{1}$, Madeline E. Michaels ${ }^{1}$, \\ Margaret Kweya Wahl ${ }^{1}$, Mark E. Stutheit ${ }^{1}$, Michelle Barnard ${ }^{1}$, Muriel Mae Ranger ${ }^{1}$, \\ Paromvong Sinbandhit ${ }^{1}$, V. J. Kris Elig ${ }^{1}$, Sambhu Charan Mondal ${ }^{2}$, Snehasis Jana ${ }^{2, ~ *}$ \\ ${ }^{1}$ Trivedi Global, Inc., Henderson, Nevada, USA \\ ${ }^{2}$ Trivedi Science Research Laboratory Pvt. Ltd., Bhopal, Madhya Pradesh, India
}

Email address:

publication@trivedieffect.com (S. Jana)

${ }^{*}$ Corresponding author

To cite this article:

Mahendra Kumar Trivedi, Alice Branton, Dahryn Trivedi, Gopal Nayak, Michael Peter Ellis, James Jeffery Peoples, James Joseph Meuer, Johanne Dodon, John Lawrence Griffin, John Suzuki, Joseph Michael Foty, Judy Weber, Julia Grace McCammon, Karen Brynes Allen, Kathryn Regina Sweas, Lezley Jo-Anne Wright, Lisa A. Knoll, Madeline E. Michaels, Margaret Kweya Wahl, Mark E. Stutheit, Michelle Barnard, Muriel Mae Ranger, Paromvong Sinbandhit, V. J. Kris Elig, Sambhu Charan Mondal, Snehasis Jana. Immunomodulatory Activity of Biofield Energy Healing Based Herbomineral Formulation in Sprague Dawley Rats: Evidence for Humoral and Cell-Mediated Responses. American Journal of Health Research. Vol. 5, No. 6, 2017, pp. 183-192. doi: 10.11648/j.ajhr.20170506.14

Received: October 30, 2017; Accepted: November 11, 2017; Published: December 11, 2017

\begin{abstract}
Herbomineral formulations are used extensively in the world-wide for the prevention and treatment of a wide range of disorders. A new proprietary herbomineral formulation was formulated consisted of an ashwagandha root extract and minerals (zinc, magnesium, and selenium). The present study was aimed to evaluate the impact of the Biofield Energy Treated herbomineral formulation in male Sprague Dawley (SD) rats for immune biomarkers modulation. The test formulation was divided into two parts. One part was denoted as the control without any Biofield Energy Treatment, while the other part was defined as the Biofield Energy Treated sample, which received the Biofield Energy Healing Treatment remotely from twenty renowned Biofield Energy Healers. The experimental parameters studies were humoral immune response (primary and secondary titre), delayed type hypersensitivity reaction, animal weight parameters, feed and water intake, histopathology, hematological and serum biochemistry. The humoral immune response exhibited that both the primary and secondary hemagglutination (HA) antibody titre levels were significantly altered by $14.79 \%$ and $12.89 \%$, respectively in the Biofield Energy Treated test formulation group (G4) compared to the disease control group (G2). The delayed type hypersensitivity (DTH) response was significantly ( $p \leq 0.05)$ increased by $55.56 \%$ in the G4 group compared to the G2 group. The hematological results revealed that the platelet count was significantly increased by $8.46 \%$ in the G4 group with respect to the G2 group. Moreover, the level of phosphorus was significantly increased by $11.16 \%$ and $16.35 \%$ in the levamisole (G3) and G4 groups, respectively compared to the G2 group. In conclusion, the Biofield Energy Treated Test Formulation would be the powerful immunomodulatory product, which was found safe at the tested doses. Therefore, The Trivedi Effect $^{\circledR}$-Biofield Energy Healing based herbomineral formulation can be applied to potentiate the immune system that helps to fight against many infectious diseases. Overall, these data suggest that the Biofield Energy Treated test formulation can be used for autoimmune and inflammatory diseases, stress management and prevention, and anti-aging by improving overall health.
\end{abstract}

Keywords: Biofield Energy Healing, Immunomodulation, Herbomineral Formulation, Humoral Immune Response, Antibody Titre, Delay Type Hypersensitivity, Stress Management and Anti-aging 


\section{Introduction}

Most of the world's population depends upon the traditional medicine as the main source of treatment. In developed and developing countries alike, medicinal plantderived drugs are continuously gaining popularity due to their natural origin and low side effects. Indigenous plants play an important role against various common ailments and chronic diseases [1]. Some medicinal plants are believed to be useful to strengthen the human immune system [2], while such plant based formulations play an important role with significant effect in the modern health care system [3]. A global reliance on alternative system of medicine for any types of ailments resulted in an intense area of research and discovery of a number of herbs and minerals with their potential to cure diseases [4]. Immunomodulation is a process, in which an organism can homeostat the immune response by either stimulation or suppression of immune system in the cells and organs [4, 5]. The Complementary and Alternative Medicine (CAM) has increased globally for the treatment and prevention of many chronic diseases in human population [6]. Number of herbs and minerals have been exploited for modulation of immune system from Ayurvedic formulation. Likewise, an herbomineral formulation was designed. The herbal remedies are amongst the most prevalent therapies due to lack of adverse effects and low cost [7]. The newly formulated herbomineral formulation, which was a combination of ashwagandha root extract along with trace elements such as zinc chloride, magnesium gluconate hydrate, and sodium selenate for immunomodulatory activity. Each constituent of this formulation commonly used as nutraceutical supplement [8-11]. Herbomineral formulations are reported to improve the general health by increasing the body's immunity. Numerous scientific reports and clinical trials had evident for the beneficial effect of Biofield Energy Treatment on immune system such as preservation of immune function in cervical cancer patients after therapeutic touch [12], massage therapy in enhancing immune system [13], and many more. The National Center for Complementary/Alternative Medicine (NCCAM) has described and given priority to the energy therapies, as it works by manipulating the energy fields that theoretically surround and penetrate the body [14].

In recent years, several scientific reports and clinical trials have revealed the useful effects of the Biofield Energy Treatment, which has shown enhanced immune function in cases of cervical cancer patients with therapeutic touch [12], massage therapy [13], etc. Complementary and Alternative Medicine (CAM) therapies are now rising as preferred models of treatment, among which Biofield Therapy (or Healing Modalities) is one approach that has been reported to have several benefits to enhance physical, mental and emotional human wellness. However, as per the data of 2012 from the National Health Interview Survey (NHIS), which comprised that the highest percentage
(17.7\%) of the Americans used dietary supplement as complementary health approaches as compared with other practices in past years. The National Center of Complementary and Integrative Health (NCCIH) has recognized and accepted Biofield Energy Healing as a CAM health care approach in addition to other therapies, medicines and practices such as natural products, deep breathing, yoga, Tai Chi, Qi Gong, chiropractic/osteopathic manipulation, meditation, massage, special diets, homeopathy, progressive relaxation, guided imagery, acupressure, acupuncture, relaxation techniques, hypnotherapy, healing touch, movement therapy, pilates, rolfing structural integration, mindfulness, Ayurvedic medicine, traditional Chinese herbs and medicines, naturopathy, essential oils, aromatherapy, Reiki, and cranial sacral therapy. Human Biofield Energy has subtle energy that has the capacity to work in an effective manner [15]. CAM therapies have been practiced worldwide with reported clinical benefits in different health disease profiles [16]. This energy can be harnessed and transmitted by individuals into living and non-living things via the process of Biofield Energy Healing. Biofield Energy Treatment (The Trivedi Effect ${ }^{\mathbb{B}}$ ) has been published in numerous peerreviewed science journals with significant outcomes in many scientific fields such as cancer research [17, 18], microbiology [19-22], genetics [23, 24], pharmaceutical science [25-28], agricultural science [29-32], and materials science [33-36].

The authors sought to evaluate the impact of the Biofield Energy Treatment (The Trivedi Effect ${ }^{\mathbb{B}}$ ) on the test herbomineral formulation for immunomodulatory action with respect to antibody titre, delayed type hypersensitivity reaction, body weight change, feed consumption, hematological parameters, and serum biochemistry using standard assays.

\section{Materials and Methods}

\subsection{Chemicals and Reagents}

Cyclophosphamide and sodium carboxymethyl cellulose were obtained from Sigma Chemical Co. (St. Louis, MO). Ashwagandha (Withania somnifera) root extract was purchased from Sanat Products Ltd., India. Zinc chloride and magnesium (II) gluconate hydrate were obtained from TCI, Japan. Sodium selenate was procured from Alfa Aesar, USA. Levamisole hydrochloride was procured from Sigma, USA. All other chemicals used in this study were analytical grade available in India.

\subsection{Laboratory Animals}

Randomly breed male Sprague Dawley (SD) rats with body weight ranges between 237 to 286 gm were used in this experiment. The animals were purchased from M/s. Vivo Bio 
Tech Ltd., Hyderabad, India. Standard rodent diet was procured from M/s. Golden feeds, Mehrauli, New Delhi, India and provided ad libitum to all the groups of animals during the experiment under controlled conditions with a temperature of $22 \pm 3^{\circ} \mathrm{C}$, humidity of $30 \%$ to $70 \%$ and a 12 hour light/12-hour dark cycle. The animals were acclimatized for the period of 5 days prior to the experiment, and all were accessed once daily for clinical signs, behaviors, morbidity and mortality. All the procedures were in strict accordance with the Guide for the Care and Use of Laboratory Animals published by the US National Institutes of Health. The approval of the Institutional Animal Ethics Committee was obtained prior to carrying out the animal experiment.

\subsection{Energy of Consciousness Treatment Strategies}

The test formulation was divided into two parts. One part of the test formulation was treated with Biofield Energy by renowned Biofield Energy Healers (also known as The Trivedi Effect ${ }^{\circledR}$ ) and coded as the Biofield Energy Treated formulation, while the second part of the test formulation did not receive any sort of treatment and was defined as the untreated test formulation. This Biofield Energy Treatment was provided through a group of twenty Biofield Energy Healers who participated in this study and performed the Biofield Energy Treatment remotely. Thirteen Biofield Energy Healers were remotely located in the U.S.A., five were located in Canada, and two were located in Australia, while the test herbomineral formulation was located in the research laboratory of Dabur Research Foundation, New Delhi, India. This Biofield Energy Treatment was administered for 5 minutes through the Healer's unique Energy Transmission process remotely to the test formulation under laboratory conditions. None of the Biofield Energy Healers in this study visited the laboratory in person, nor had any contact with the herbomineral samples. Further, the control group was treated with a "sham" healer for comparative purposes. The sham healer did not have any knowledge about the Biofield Energy Treatment. After that, the Biofield Energy Treated and untreated samples were kept in similar sealed conditions and used for identification of immunological parameters.

\subsection{Antigen (Sheep RBC, sRBC)}

The fresh sheep blood was collected aseptically from the jugular vein of a healthy sheep and transferred immediately to the heparinized tube. The collected erythrocytes were separated from plasma by centrifugation $\left(400 \mathrm{~g}, 10^{\circ} \mathrm{C}, 10\right.$ minutes), washed twice with the normal saline and then further diluted in saline, which were analyzed using a Hematology analyzer (Abbott Model-CD-3700). Based on the number of erythrocytes, the samples were further diluted (using saline) before injecting to the rat [37].

\subsection{Experimental Procedure}

The animals were randomized and grouped according to their body weight. A total of five groups $(G)$ were included i.e. Group 1 (G1) was served as a normal control (i.e. vehicle control), and G2 was served as a disease control; both the groups were received $0.5 \% \mathrm{Na}-\mathrm{CMC}$, while G3 group animals received levamisole at $75 \mathrm{mg} / \mathrm{kg}$ per oral (p.o.). G4 group animals were received Biofield Energy Treated test formulation at a dose of $1105.005 \mathrm{mg} / \mathrm{kg}$. Similarly, G5 animals were received untreated test formulation at a same dose. However, during the experimental period, all the animals except normal control (G1) were received with cyclophosphamide $(10 \mathrm{mg} / \mathrm{kg}$, p.o.) daily to induce the immunosuppression action. Cyclophosphamide was given 1 hour prior to the oral administration of test formulation for initial period of 13 days. The treatment was continued to all the tested groups (G1 to G5) with $5 \mathrm{~mL} / \mathrm{kg}$ body weight dose volume for 22 day experiment. Further, on day 7 and 13, all the groups (G1 to G5) received sRBC $\left(0.5 \times 10^{9} / 100\right.$ gm body weight; i.p.). On day 13 and 20, blood was withdrawn from retro orbital plexus under isoflurane anesthesia and the serum was separated for hemagglutination assay. On day 20, the animals were challenged with $\operatorname{sRBC}\left(0.5 \times 10^{9}\right.$ cells $/ 100$ $\mu \mathrm{L} / \mathrm{rat}$ ) in right paw, while on day 21 and 22 , the paw thickness was measured using micrometer (MITUTOYO, Japan). The body weight, food intake, and water intake were measured daily before the treatment. On day 22, the animals were kept under overnight fasting and on day 23 blood was withdrawn from retro orbital plexus under isoflurane anesthesia. At the end of the study; animals were euthanized by $\mathrm{CO}_{2}$ asphyxiation as per in-house approved standard protocol. Different organs of all animals were excised, weighed and preserved for histopathological analysis.

\subsection{Hemagglutination Antibody Titre}

Approximately $25 \mu \mathrm{L}$ of serum was serially diluted with the $25 \mu \mathrm{L}$ of phosphate-buffered saline. The sRBC $(0.025 \mathrm{x}$ $10^{9}$ cells) was added to each of these dilutions and incubated at $37^{\circ} \mathrm{C}$ for 1 hour. The rank of minimum dilution that exhibited hemagglutination was considered as an antibody titre. The level of antibody titre on day 13 of the experiment was considered as the "primary humoral immune response" and the day 20 was considered as the "secondary humoral immune response" [38, 39].

\subsection{Determination of Paw Volume (Delayed Type Hypersensitivity)}

The cellular immune response was assayed by the footpad reaction method. The edema was induced in the right paw of rats by injecting $\mathrm{sRBC}\left(0.5 \times 10^{9}\right.$ cells $)$ in the sub-plantar region. The increase in the paw thickness in 24 and 48 hours, i.e. on day 21 and 22 was assessed using a micrometer (MITUTOYO, Japan). The thickness of the left hind paw, injected similarly with normal saline, served as control. The mean percentage increase in paw thickness in comparison to control was considered as a delayed type of hypersensitivity and as an index of cell-mediated immunity [40]. 


\subsection{Determination of Hematological and Biochemical Parameters}

After fasting for 12 to 16 hours, blood was collected from the retro-orbital plexus using heparinized or non-heparinized capillary tubes. One portion of the blood was kept in plain bottles from which serum was collected and stored for biochemical analysis. The other portion was directly subjected for the estimation of various hematological parameters using standard instruments. The levels of hemoglobin $(\mathrm{Hb})$, red blood cell count $(\mathrm{RBC})$, packed cell volume (PCV), mean corpuscular volume (MCV), mean corpuscular hemoglobin $(\mathrm{MCH})$, mean corpuscular hemoglobin concentration (MCHC) and platelets were analyzed in the blood samples in all experimental groups. Further, the levels of magnesium, blood urea, creatinine, uric acid, calcium, phosphorus, potassium, sodium, and chloride ion concentration were analyzed using Hematology analyzer (Abbott Model-CD-3700) [41].

\subsection{Determination of Body Weight, Feed Intake and Water Intake}

The body weight, feed intake, and water intake were measured once daily before the test item administration throughout the experiment. In brief, the weight of the daily feed intake was calculated from the difference between the weight of daily feed supply and the left-over feed was taken as the daily feed intake [42].

\subsection{Clinical Sign and Symptoms}

The clinical signs and symptoms were observed once daily in all the groups as per in-house standard protocol throughout the experiment. Animals found in a moribund condition or enduring signs of severe distress was humanely euthanized [43].

\subsection{Measurement of Relative Organ Weight and Histopathology}

At the end of the study; animals were euthanized by $\mathrm{CO}_{2}$ asphyxiation as per in-house standard protocol. Different organs of all animals were excised, weighed and preserved for histopathological analysis viz. the whole liver, lungs, kidneys, brain, hearts, eyes, spleens, duodenum, jejunum, ileum, caecum, colon, rectum, testis, prostate, epididymis, vas-deference, and pancreas. In brief, the organs were trimmed off for any adherent tissue and fat, as appropriate and were weighed wet as soon as possible to avoid drying. The organ to body weight ratio of each rat was determined by comparing the absolute weight of each organ with the final body weight. The collected tissues were placed in $10 \%$ neutral buffered formalin for histopathological examination. Eyes and testis were fixed in Davidson's fixative and modified Davidson fluid, respectively for 24 hour and followed by $70 \%$ alcohol for 48 hour. After that, all the organs were subjected to histopathology as per standard protocol [44, 45].

Relative organ weight was calculated using the formula mentioned below-

$$
\begin{aligned}
& \text { Relative organ weight } \\
& =\text { Absolute organ weight(g) } \\
& \text { /weight of rat on sacrifice day(g)X100 }
\end{aligned}
$$

\subsection{Statistical Analysis}

Sigma-plot (v11.0) was used for all statistical analysis. Data are presented as mean \pm standard error of mean (SEM) and analyzed by Student's $t$-test; $p \leq 0.05$ was considered statistically significant.

\section{Results and Discussion}

\subsection{Effect of the Test Formulation on Humoral Immune Response}

The antigen-antibody reaction results in agglutination. The relative strength of an antibody titre is defined as the reciprocal of the highest dilution, which is still capable of causing visible agglutination. The antibody titre is a useful tool to measure the changes in the amount of the antibody in the course of an immune response [6]. The primary and secondary humoral immune responses after oral administration of the test formulation in male Sprague Dawley rats are shown in the Table 1 . Both the primary and secondary responses of mean hemagglutination (HA) antibody titre were significantly $(p \leq 0.001)$ decreased by $66.20 \%$ and $66.25 \%$ in the disease control group (G2) compared to the normal control group (G1). It was indicated that cyclophosphamide remarkably suppressed the immunoresponse as evident by lowered the level of both primary and secondary titres. The primary and secondary HA titre levels were suppressed by $14.79 \%$ and $12.89 \%$, respectively in the Biofield Energy Treated test formulation group (G4) compared to the G2 group. Besides, both the primary and secondary HA titre levels were raised significantly by $47.93 \%$ and $74.07 \%$, respectively in the untreated test formulation group (G5) compared to the G2 group. It was indicated that the Biofield Energy Treated test formulation showed immunosuppressive response in comparison with the disease control group (G2). It is assumed that the decreased levels of both primary and secondary antibody titre in the Biofield Energy Treated test formulation group (G4) might be due to Biofield Energy Healing through Biofield Energy Transmission to the test formulation. In contrary, the primary HA titre response was significantly raised by $25.74 \%$, while the secondary response was reduced minimally in the levamisole group (G3) compared to the disease control (G2). It is presumed that the Biofield Energy Treated herbomineral formulation possess potential immunomodulatory activities. 
Table 1. Effect of the test formulation on hemagglutination (HA) antibody titre using $s R B C$ as an antigen in male Sprague Dawley rats.

\begin{tabular}{lll}
\hline Group & Primary HA titre & Secondary HA titre \\
\hline G1 & $10.00 \pm 1.31$ & $20.00 \pm 2.62$ \\
G2 & $3.38 \pm 0.78^{* * *}$ & $6.75 \pm 3.70^{*}$ \\
G3 & $4.25 \pm 0.59$ & $6.50 \pm 3.73$ \\
G4 & $2.88 \pm 0.79$ & $5.88 \pm 1.85$ \\
G5 & $5.00 \pm 1.73$ & $11.75 \pm 4.72$ \\
\hline
\end{tabular}

Values are expressed as mean \pm SEM, $n=8$ in each group. The primary response of mean hemagglutination (HA) antibody titre value was recorded on day $13^{\text {th }}$ and secondary response on day $20^{\text {th }}$ of the experimental period. G: Group; G1: Normal control; G2: Disease control; G3: Reference item (Levamisole); G4: Biofield Energy Treated test formulation; G5: Untreated test formulation. ${ }^{*} \mathrm{p} \leq 0.05$ and ${ }^{* * *} \mathrm{p} \leq 0.001$ vs normal control.

\subsection{Estimation of Delayed Type Hypersensitivity (Paw Volume)}

The effect of the test formulation on delayed type hypersensitivity (DTH) response $\mathrm{SBC}$ was injected in paw (sub-plantar) and paw thickness was measured at 24 and 48 hours after post injection is shown in the Figure 1. The paw thickness was significantly decreased by $29.69 \%$ at 24 hours; while it was increased by $53.57 \%$ at 48 hours in the disease control group (G2) compared to the normal control (G1). The paw thickness was significantly $(p \leq 0.05)$ increased by $55.56 \%$ in the Biofield Energy Treated test formulation (G4) at 24 hours; however paw thickness was unaltered at 48 hours compared to the $\mathrm{G} 2$ group. In the early hypersensitivity reaction, the antigen-antibody forms immune complexes, which are known to induce local inflammation with increased vascular permeability and edema [6]. Naik et al. (2015) documented that ashwagandha increased the animal paw thickness [46], moreover zinc was also reported to increase the DTH reaction [47]. Therefore, it can be concluded that the constituents present in this formulation are responsible for DTH reaction. The Biofield Energy Treated (The Trivedi Effect $^{\circledR}$ ) test formulation (G4) showed better cellular immune response compared with the untreated test formulation (G5).
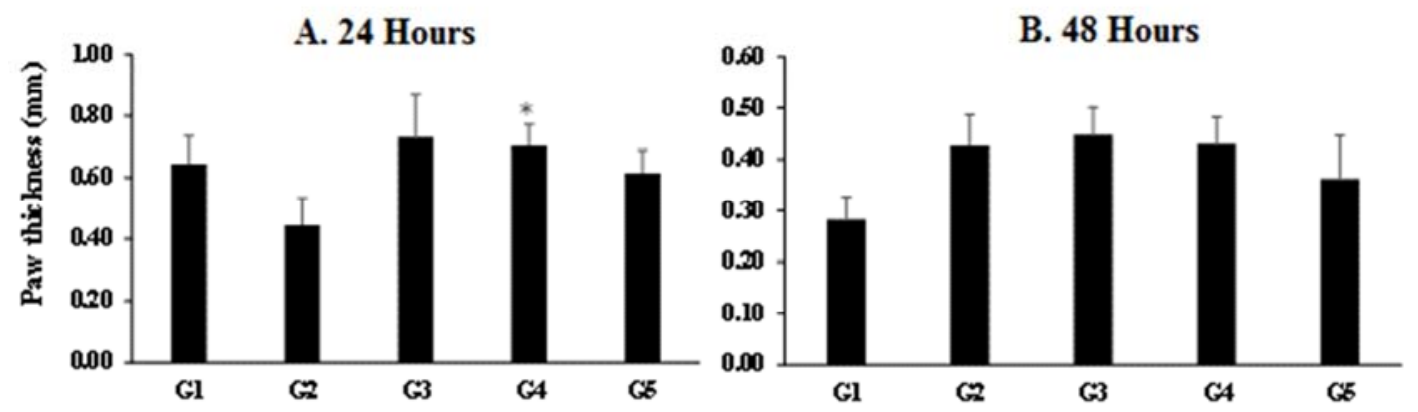

Figure 1. Effect of the test formulation on paw thickness (delayed type hypersensitivity) in Sprague Dawley rats. G1: Normal control; G2: Disease control: G3: Levamisole; G4: Biofield Energy Treated test formulation; G5: Untreated test formulation. All the values are expressed as the mean \pm SEM (n = 8). ${ }^{*} \leq 0.05$ vs disease control.

\subsection{Effect of the Test Formulation on Hematological Parameters}

The effect of the test formulation on hematological parameters is shown in the Table 2. Results showed the platelet count was significantly increased by $8.46 \%$ and $1.54 \%$ in the Biofield Energy Treated test formulation group (G4) and untreated test formulation group (G5), respectively with respect to the disease control group $(\mathrm{G} 2)$. It was indicated that the Biofield Energy Treated test formulation group showed more increment of platelets counts compared to the untreated test formulation group; which might be due to the Biofield Energy Healing Treatment. Moreover, the platelet count was increased by $6.15 \%$ in the levamisole group (G3) compared to the G2. Overall, it was indicated that the Biofield Energy Treated test formulation improved the platelet counts compared to the both G2 and G5 groups. From the literature, it was reported that ashwagandha prevented myelosuppression and increased in the platelet count and body weight [48, 49]. Our experimental finding showed increased platelet count, which could be due to Biofield Energy Healing Treatment to the test formulation. Rest of the parameters such as RBC, Hb, MCHC, PCV, MCV and $\mathrm{MCH}$ were altered minimally compared to the $\mathrm{G} 2$ group. It is assumed that these parameters were unaffected by the Biofield Energy Treatment.

Table 2. Evaluation of hematology parameters after treatment with the test formulation in experimental rat.

\begin{tabular}{|c|c|c|c|c|c|c|c|c|}
\hline Group & $\begin{array}{l}\text { RBC } \\
\left(10^{6} / \mu \mathbf{L}\right)\end{array}$ & $\begin{array}{l}\text { Hb } \\
(\mathrm{gm} / \mathrm{dL})\end{array}$ & $\begin{array}{l}\text { PCV } \\
(\%) \\
\end{array}$ & $\begin{array}{l}\text { MCV } \\
\text { (fl) }\end{array}$ & $\begin{array}{l}\text { MCH } \\
(\mathrm{pg})\end{array}$ & $\begin{array}{l}\text { MCHC } \\
(\%)\end{array}$ & $\begin{array}{l}\text { Platelet Count } \\
\left(\text { thou } / \mathrm{mm}^{3}\right)\end{array}$ & RDW-CV \\
\hline G1 & $10.16 \pm 0.30$ & $17.55 \pm 0.51$ & $59.89 \pm 1.83$ & $58.94 \pm 0.69$ & $17.24 \pm 0.18$ & $29.29 \pm 0.43$ & $793.75 \pm 68.42$ & $0.14 \pm 0.00$ \\
\hline G2 & $9.49 \pm 0.30$ & $16.93 \pm 0.55$ & $58.06 \pm 1.73$ & $61.34 \pm 1.03$ & $17.79 \pm 0.15$ & $29.13 \pm 0.30$ & $812.50 \pm 67.31$ & $0.15 \pm 0.00$ \\
\hline G4 & $8.81 \pm 0.36$ & $15.74 \pm 0.25$ & $53.51 \pm 0.69$ & $58.33 \pm 0.58$ & $17.13 \pm 0.38$ & $29.44 \pm 0.40$ & $881.25 \pm 79.02$ & $0.14 \pm 0.00$ \\
\hline G5 & $9.00 \pm 0.19$ & $15.94 \pm 0.39$ & $53.20 \pm 1.35$ & $59.16 \pm 0.67$ & $17.66 \pm 0.10$ & $29.94 \pm 0.18$ & $825.00 \pm 57.48$ & $0.14 \pm 0.00$ \\
\hline
\end{tabular}

All the values are expressed as the mean \pm SEM. G1: Normal control; G2: Disease control; G3: Reference item (Levamisole); G4: Biofield Energy Treated test formulation; G5: Untreated test formulation. 


\subsection{Effect of the Test Formulation on Biochemistry Parameters}

The effect of the test formulation on different biochemical parameters is shown in the Table 3. The level of phosphorus was significantly increased by $11.16 \%, 16.35 \%$, and $23.54 \%$ in the levamisole (G3), Biofield Energy Treated test formulation (G4), and untreated test formulation group (G5), respectively compared to the $\mathrm{G} 2$ group. The results might be due to the positive effect of the Biofield Energy Healing to the novel herbomineral product, which could be very helpful to the patients in the near future. Besides, the levels of magnesium, blood area, creatinine, uric acid, calcium, and ions like sodium, potassium, and chloride were altered in all the tested groups to some extent but did not show any significant difference with respect to the disease control group (G2). Altogether, on the assessment of serum chemistry profile exhibited a significant increased the level of serum phosphorus in the Biofield Energy Treated test formulation group (G4) compared to the G2 group.

Table 3. Estimation of biochemical parameters after the treatment with the test formulation in experimental rats.

\begin{tabular}{|c|c|c|c|c|c|c|c|c|c|}
\hline Group & $\begin{array}{l}\text { Magnesium } \\
(\mathrm{mg} / \mathrm{dL})\end{array}$ & $\begin{array}{l}\text { Blood Urea } \\
(\mathrm{mg} / \mathrm{dL})\end{array}$ & $\begin{array}{l}\text { Creatinine } \\
(\mathrm{mg} / \mathrm{dL})\end{array}$ & $\begin{array}{l}\text { Uric Acid } \\
(\mathrm{mg} / \mathrm{dL})\end{array}$ & $\begin{array}{l}\text { Calcium } \\
(\mathrm{mg} / \mathrm{dL})\end{array}$ & $\begin{array}{l}\text { Phosphorus } \\
\text { (mg/dL) }\end{array}$ & $\mathrm{Na}^{+}(\mathrm{Meq} / \mathrm{L})$ & $\begin{array}{l}\mathrm{K}^{+} \\
(\mathrm{mEq} / \mathrm{L})\end{array}$ & $\mathrm{Cl}^{-}(\mathrm{mEq} / \mathrm{L})$ \\
\hline G1 & $6.30 \pm 0.02$ & $26.99 \pm 1.42$ & $0.30 \pm 0.02$ & $0.75 \pm 0.11$ & $10.06 \pm 0.13$ & $9.64 \pm 0.28$ & $151.03 \pm$ & $5.04 \pm 0.10$ & 6.32 \\
\hline G2 & $6.32 \pm 0.02$ & $31.85 \pm 1.83$ & $0.29 \pm 0.01$ & $0.69 \pm 0.13$ & $9.59 \pm 0.18$ & $9.05 \pm 0.15$ & $151.04 \pm 0.86$ & $5.19 \pm 0.14$ & $105.25 \pm 0.88$ \\
\hline G3 & $6.35 \pm 0.02$ & $35.40 \pm 2.24$ & $0.69 \pm 0.28$ & $0.71 \pm 0.12$ & $10.35 \pm 0.27$ & $10.06 \pm 0.23$ & $150.21 \pm 0.25$ & $4.99 \pm 0.09$ & $107.75 \pm 1.81$ \\
\hline G4 & $6.32 \pm 0.02$ & $32.78 \pm 0.66$ & $0.30 \pm 0.01$ & $0.83 \pm 0.16$ & $9.85 \pm 0.11$ & $10.53 \pm 0.25$ & $152.09 \pm 1.02$ & $5.19 \pm 0.11$ & $106.06 \pm 1.41$ \\
\hline G5 & $6.34 \pm 0.02$ & $32.13 \pm 1.65$ & $0.29 \pm 0.01$ & $0.65 \pm 0.08$ & $9.89 \pm 0.12$ & $11.18 \pm 0.22$ & $151.94 \pm 1.01$ & $5.21 \pm 0.12$ & $108.00 \pm 1.60$ \\
\hline
\end{tabular}

All the values are expressed as the mean \pm SEM. G1: Normal control; G2: Disease control; G3: Reference item (Levamisole); G4: Biofield Energy Treated test formulation; G5: Untreated test formulation.

\subsection{Effect of the Test Formulation on Body Weight and Organ to Body Weight Ratio}

The results of animal weight parameters such as animal body weight, and respective organ weight obtained after oral administration of the test formulation are summarized in the Table 4. The initial mean body weight was $269.51 \pm 5.53$, $269.92 \pm 3.56,271.52 \pm 4.94,270.21 \pm 3.76$, and $269.43 \pm$ 3.40 gm from group G1 to G5, respectively. However, final body weight in all the group were increased i.e. $385.69 \pm$ $7.53,351.20 \pm 6.60,321.27 \pm 10.10,336.42 \pm 12.27$, and $356.63 \pm 5.91 \mathrm{gm}$ from group G1 to G5, respectively. Thus, overall data of body weight analysis visualized no significant change in body weight with respect to the disease control group, it suggest that the test formulation was found to be safe in all the tested animal groups.

Table 4. Effect of the test formulation on various vital organs in male Sprague Dawley rats.

\begin{tabular}{|c|c|c|c|c|c|}
\hline Relative organ weight (\%) & G1 & G2 & G3 & G4 & G5 \\
\hline Liver & $3.71 \pm 0.14$ & $4.08 \pm 0.13$ & $4.79 \pm 0.15$ & $4.27 \pm 0.11$ & $4.52 \pm 0.10$ \\
\hline Lungs & $0.65 \pm 0.06$ & $0.96 \pm 0.07$ & $1.04 \pm 0.10$ & $0.84 \pm 0.05$ & $0.92 \pm 0.04$ \\
\hline Kidneys & $0.90 \pm 0.05$ & $0.90 \pm 0.02$ & $1.04 \pm 0.02$ & $0.94 \pm 0.02$ & $0.93 \pm 0.02$ \\
\hline Brain & $0.59 \pm 0.01$ & $0.64 \pm 0.02$ & $0.71 \pm 0.03$ & $0.67 \pm 0.03$ & $0.62 \pm 0.02$ \\
\hline Heart & $0.38 \pm 0.01$ & $0.44 \pm 0.01$ & $0.43 \pm 0.02$ & $0.44 \pm 0.02$ & $0.42 \pm 0.02$ \\
\hline Eyes & $0.07 \pm 0.00$ & $0.08 \pm 0.00$ & $0.09 \pm 0.00$ & $0.09 \pm 0.00$ & $0.08 \pm 0.00$ \\
\hline Spleen & $0.22 \pm 0.01$ & $0.24 \pm 0.01$ & $0.21 \pm 0.01$ & $0.20 \pm 0.01$ & $0.22 \pm 0.02$ \\
\hline Pancreas & $0.71 \pm 0.08$ & $0.63 \pm 0.02$ & $0.68 \pm 0.04$ & $0.60 \pm 0.05$ & $0.65 \pm 0.04$ \\
\hline Duodenum & $0.24 \pm 0.01$ & $0.29 \pm 0.02$ & $0.37 \pm 0.02$ & $0.39 \pm 0.03$ & $0.37 \pm 0.02$ \\
\hline Jejunum & $1.42 \pm 0.05$ & $1.64 \pm 0.11$ & $1.74 \pm 0.06$ & $1.90 \pm 0.10$ & $1.91 \pm 0.11$ \\
\hline Ileum & $0.31 \pm 0.02$ & $0.34 \pm 0.02$ & $0.34 \pm 0.02$ & $0.45 \pm 0.03$ & $0.46 \pm 0.05$ \\
\hline Caecum & $0.53 \pm 0.03$ & $0.51 \pm 0.03$ & $0.56 \pm 0.04$ & $0.64 \pm 0.03$ & $0.53 \pm 0.03$ \\
\hline Colon & $0.33 \pm 0.02$ & $0.40 \pm 0.02$ & $0.50 \pm 0.02$ & $0.37 \pm 0.02$ & $0.41 \pm 0.01$ \\
\hline Rectum & $0.14 \pm 0.01$ & $0.20 \pm 0.01$ & $0.20 \pm 0.02$ & $0.19 \pm 0.01$ & $0.18 \pm 0.02$ \\
\hline Prostate & $0.18 \pm 0.01$ & $0.22 \pm 0.02$ & $0.20 \pm 0.03$ & $0.21 \pm 0.01$ & $0.19 \pm 0.01$ \\
\hline Epididymis & $0.33 \pm 0.01$ & $0.38 \pm 0.02$ & $0.36 \pm 0.01$ & $0.35 \pm 0.04$ & $0.35 \pm 0.02$ \\
\hline Vas deference & $0.07 \pm 0.00$ & $0.07 \pm 0.00$ & $0.08 \pm 0.00$ & $0.08 \pm 0.01$ & $0.06 \pm 0.00$ \\
\hline
\end{tabular}

All the values are expressed as the mean \pm SEM. G1: Normal control; G2: Disease control; G3: Reference item (Levamisole); G4: Biofield Energy Treated test formulation; G5: Untreated test formulation.

The relative organ weight is a useful index for the identification of swelling, atrophy or hypertrophy [50]. The increase organ to body weight ratio might be correlated with the sign of product toxicity, but the experimental results suggested that there was not much change in most of the vital organs, which depicts that the test formulation was non-toxic to the animals throughout the exposure period ( 23 days) at the dose rate of $1105.005 \mathrm{mg} / \mathrm{kg}$. 


\subsection{Assessment of Animal Feed and Water Intake}

The results of animal feed and water intake are presented as mean values throughout the study period in the Table 5 . There was no significant alteration observed in the feed intake in all the groups. The water intake was gradually increased in across to all the groups as shown in Table 5. These findings suggest that there was no significant changes observed in terms of feed intake and water intake. Based on these results, it can be inferred that the oral administration of Biofield Energy Treated test formulation was found to be safe.

Table 5. The effect of the test formulation on feed intake and water intake in male Sprague Dawley rats.

\begin{tabular}{lllll}
\hline \multirow{2}{*}{ Group } & Feed Intake $(\mathbf{g})$ & Water intake $(\mathbf{m L})$ & Final \\
\cline { 2 - 5 } & Initial & Final & Initial & $45.33 \pm 2.22$ \\
G1 & $24.18 \pm 0.93$ & $27.35 \pm 0.57$ & $35.10 \pm 2.22$ & $44.67 \pm 2.23$ \\
G2 & $21.94 \pm 0.76$ & $27.80 \pm 0.70$ & $32.72 \pm 1.76$ & $45.91 \pm 2.45$ \\
G3 & $17.84 \pm 1.12$ & $24.13 \pm 0.42$ & $31.72 \pm 2.48$ & $46.23 \pm 1.97$ \\
G4 & $21.83 \pm 0.83$ & $25.81 \pm 0.77$ & $35.48 \pm 2.30$ & $42.66 \pm 1.88$ \\
G5 & $21.59 \pm 0.92$ & $27.61 \pm 0.71$ & $34.56 \pm 1.91$ & \\
\hline
\end{tabular}

All the values are expressed as mean \pm SEM $(n=8)$. G1: Normal control; G2: Disease control; G3: Reference item (Levamisole); G4: Biofield Energy Treated test formulation; G5: Untreated test formulation.

\subsection{Assessment of Histopathological Examination}

The effect of the test formulation on histopathological findings in male SD rats is shown in Figure 2. No significant differences were observed either in gross and microscopic observation of the tested organs. Histopathological findings suggest that no Biofield Energy Healing related histopathological changes were observed in all the experimental animals compared with the normal control group.

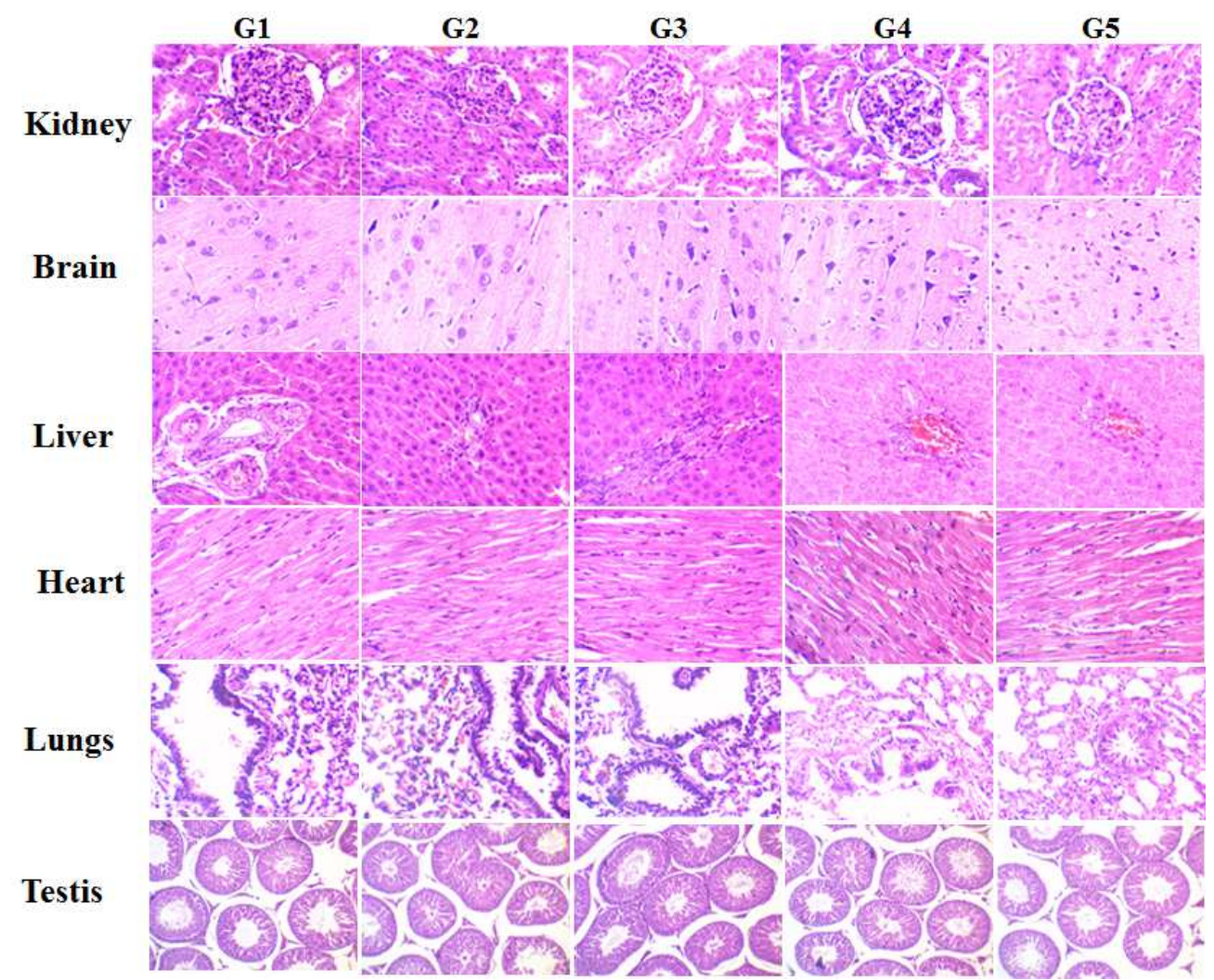

Figure 2. Histopathological photomicrograph of major organs of male Sprague Dawley rats. All the tissues were sectioned transversely and stained with hematoxylin and eosin. G1: Normal control; G2: Disease control; G3: Levamisole; G4: Biofield Energy Treated test formulation; G5: Untreated test formulation.

The National Center for Complementary/Alternative Medicine (NCCAM,) reported that about $34 \%$ U.S. populations depends on some forms of complementary health approach, among which energy medicine is one of them. CAM has huge positive aspect as compared to the conventional treatment strategy [51]. Overall study findings envisaged that the novel herbomineral formulation could be anti-inflammatory and immunomodulatory effect and might produce as a better immunomodulatory medicine in the near future. Although the herbomineral formulation could be 
beneficial due to the combination of multiple compounds, which might have synergetic effect along with minimal sideeffect of the constituent. Therefore, it is assumed that the Biofield Energy Treated herbomineral formulation might be considered as a safe dietary supplement and more powerfull product for boosting the immunity in healthy human and patient.

\section{Conclusions}

Results of our study revealed that, the humoral immune response of both the primary and secondary hemagglutination (HA) antibody titre levels were significantly altered by $14.79 \%$ and $12.89 \%$, respectively in the Biofield Energy Treated test formulation group (G4) compared to the disease control group $(\mathrm{G} 2)$. The delayed type hypersensitivity (DTH) response was significantly $(p \leq 0.05)$ increased by $55.56 \%$ in the G4 group compared to the G2 group. Besides, the platelet count was significantly increased by $8.46 \%$ in the G4 group with respect to the G2 group. The level of phosphorus was significantly increased by $11.16 \%$ in the G4 group compared to the G2 group. Further, no treatment-related changes were observed in the G4 group with respect to the body weight, feed consumption and water intake, relative organ weight, and histopathological findings during the course of the experiment. Overall, the change in above weight parameters were consistent throughout the study, which suggest that the Biofield Energy Treated test formulation has safe nutritional status with respect to the physiological and metabolic changes.

Therefore, the current findings conclude The Trivedi Effect ${ }^{\circledR}$-Biofield Energy Healing administered remotely by the twenty Biofield Energy Healers enhanced the herbomineral test formulation's anti-inflammatory and immunomodulatory properties without any side effect, which can be used as a herbomineral product to improve the overall health. Thus, the Biofield Energy Treated test formulation may act as an effective anti-inflammatory and immunomodulatory product, and it can be used as a Complementary and Alternative Medicine (CAM) with a safe therapeutic index for various autoimmune disorders such as Lupus, Systemic Lupus Erythematosus, Fibromyalgia, Addison Disease, Hashimoto Thyroiditis, Celiac Disease (gluten-sensitive enteropathy), Multiple Sclerosis, Dermatomyositis, Graves' Disease, Myasthenia Gravis, Pernicious Anemia, Aplastic Anemia, Scleroderma, Psoriasis, Rheumatoid Arthritis, Reactive Arthritis, Type 1 Diabetes, Sjogren Syndrome, Crohn's Disease, Vasculitis, Vitiligo, Chronic Fatigue Syndrome and Alopecia Areata, as well as inflammatory disorders such as Irritable Bowel Syndrome (IBS), Asthma, Ulcerative Colitis, Alzheimer's Disease, Parkinson's Disease, Atherosclerosis, Dermatitis, Hepatitis, and Diverticulitis. Further, the Biofield Energy Healing Treated test formulation can also be used in the prevention of immune-mediated tissue damage in cases of organ transplants (for example heart transplants, kidney transplants and liver transplants), for anti-aging, stress prevention and management, and in the improvement of overall health and quality of life.

\section{Acknowledgements}

The authors are grateful to Dabur Research Foundation, Trivedi Science, Trivedi Global, Inc., and Trivedi Master Wellness for their support throughout the work.

\section{References}

[1] Phillipson JD (1994) Natural products as drugs. Trans Royal Soc Trop Med Hyg 88: S17-S19.

[2] Khan S, Balick MJ (2001) Therapeutic plants of Ayurveda: A review of selected clinical and other Studies for 166 Species. J Altern Complement Med 7: 405-515.

[3] Patwardhan B, Chorghade M (2004) Ayurveda and natural products drug discovery. Curr Sci 86: 789-798.

[4] Patel P, Basheeruddin Asdaq SM (2010) Immunomodulatory activity of methanolic fruit extract of Aegle marmelos in experimental animals. Saudi Pharm J 18: 161-165.

[5] Heroor S, Beknal A, Mahurkar N (2012) Preliminary investigation for immunomodulation of methanolic extracts of leaves and flowers of Pongamia glabra Vent. in mice model. Adv Lif Sci 2: 170-173.

[6] Farhath S, Vijaya PP, Vima M (2013) Immunomodulatory activity of geranial, geranial acetate, gingerol, and eugenol essential oils: Evidence for humoral and cell-mediated responses. Avicenna J Phytomed 3: 224-230.

[7] MacLennan AH, Wilson DH, Taylor AW (1996) Prevalence and cost of alternative medicine in Australia. Lancet 347: 569 -573 .

[8] Houston M (2014) The role of nutrition and nutraceutical supplements in the treatment of hypertension. World J Cardiol 6: $38-66$.

[9] Bishop WM, Zubeck HM (2012) Evaluation of microalgae for use as nutraceuticals and nutritional supplements. J Nutr Food Sci 2: 147.

[10] Houston M (2013) Nutrition and nutraceutical supplements for the treatment of hypertension: Part I. J Clin Hypertens (Greenwich) 15: 752-757.

[11] Qureshi NA, Al-Bedah AM (2013) Mood disorders and complementary and alternative medicine: A literature review. Neuropsychiatr Dis Treat 9: 639-658.

[12] Lutgendorf SK, Mullen-Houser E, Russell D, Degeest K, Jacobson G, Hart L, Bender D, Anderson B, Buekers TE, Goodheart MJ, Antoni MH, Sood AK, Lubaroff DM (2010) Preservation of immune function in cervical cancer patients during chemoradiation using a novel integrative approach. Brain, behavior, and immunity 24: 1231-1240.

[13] Ironson G, Field T, Scafidi F, Hashimoto M, Kumar M, Kumar A, Price A, Goncalves A, Burman I, Tetenman C, Patarca R, Fletcher MA (1996) Massage therapy is associated with enhancement of the immune system's cytotoxic capacity. Int J Neurosci 84: 205-217. 
[14] Koithan M (2009) Introducing complementary and alternative therapies. J Nurse Pract 5: 18-20.

[15] Jain S, Hammerschlag R, Mills P, Cohen L, Krieger R, Vieten C, Lutgendorf S (2015) Clinical studies of biofield therapies: Summary, methodological challenges, and recommendations. Glob Adv Health Med 4: 58-66.

[16] Rubik B (2002) The biofield hypothesis: Its biophysical basis and role in medicine. J Altern Complement Med 8: 703-717.

[17] Trivedi MK, Patil S, Shettigar H, Mondal SC, Jana S (2015) The potential impact of biofield treatment on human brain tumor cells: A time-lapse video microscopy. J Integr Oncol 4: 141.

[18] Trivedi MK, Patil S, Shettigar H, Gangwar M, Jana S (2015) In vitro evaluation of biofield treatment on cancer biomarkers involved in endometrial and prostate cancer cell lines. J Cancer Sci Ther 7: 253-257.

[19] Trivedi MK, Patil S, Shettigar H, Mondal SC, Jana S (2015) In vitro evaluation of biofield treatment on Enterobacter cloacae: Impact on antimicrobial susceptibility and biotype. J Bacteriol Parasitol 6: 241.

[20] Trivedi MK, Patil S, Shettigar H, Mondal SC, Jana S (2015) Evaluation of biofield modality on viral load of hepatitis B and C Viruses. J Antivir Antiretrovir 7: 083-088.

[21] Trivedi MK, Patil S, Shettigar H, Mondal SC, Jana S (2015) An impact of biofield treatment: Antimycobacterial susceptibility potential using BACTEC 460/MGIT-TB System. Mycobact Dis 5: 189.

[22] Trivedi MK, Branton A, Trivedi D, Nayak G, Mondal SC, Jana S (2015) Antimicrobial sensitivity, biochemical characteristics and biotyping of Staphylococcus saprophyticus: An impact of biofield energy treatment. J Women's Health Care 4: 271.

[23] Trivedi MK, Branton A, Trivedi D, Nayak G, Mondal SC, Jana S (2015) Evaluation of antibiogram, genotype and phylogenetic analysis of biofield treated Nocardia otitidis. Biol Syst Open Access 4: 143.

[24] Trivedi MK, Branton A, Trivedi D, Nayak G, Charan S, Jana S (2015) Phenotyping and 16S rDNA analysis after biofield treatment on Citrobacter braakii: A urinary pathogen. J Clin Med Genom 3: 129.

[25] Trivedi MK, Patil S, Shettigar H, Bairwa K, Jana S (2015) Spectroscopic characterization of chloramphenicol and tetracycline: An impact of biofield. Pharm Anal Acta 6:395.

[26] Trivedi MK, Patil S, Shettigar H, Bairwa K, Jana S (2015) Spectroscopic characterization of biofield treated metronidazole and tinidazole. Med Chem 5: 340-344.

[27] Trivedi MK, Patil S, Shettigar H, Bairwa K, Jana S (2015) Effect of biofield treatment on spectral properties of paracetamol and piroxicam. Chem Sci J 6: 98.

[28] Trivedi MK, Branton A, Trivedi D, Shettigar H, Bairwa K, Jana S (2015) Fourier transform infrared and ultravioletvisible spectroscopic characterization of biofield treated salicylic acid and sparfloxacin. Nat Prod Chem Res 3: 186.

[29] Trivedi MK, Branton A, Trivedi D, Nayak G, Gangwar M, Jana S (2016) Molecular analysis of biofield treated eggplant and watermelon crops. Adv Crop Sci Tech 4: 208.
[30] Trivedi MK, Branton A, Trivedi D, Nayak G, Mondal SC, Jana S (2015) Morphological characterization, quality, yield and DNA fingerprinting of biofield energy treated alphonso mango (Mangifera indica L.). Journal of Food and Nutrition Sciences 3: 245-250.

[31] Trivedi MK, Branton A, Trivedi D, Nayak G, Mondal SC, Jana S (2015) Evaluation of plant growth, yield and yield attributes of biofield energy treated mustard (Brassica juncea) and chick pea (Cicer arietinum) seeds. Agriculture, Forestry and Fisheries 4: 291-295.

[32] Trivedi MK, Branton A, Trivedi D, Nayak G, Mondal SC, Jana S (2015) Evaluation of plant growth regulator, immunity and DNA fingerprinting of biofield energy treated mustard seeds (Brassica juncea). Agriculture, Forestry and Fisheries 4: 269-274.

[33] Trivedi MK, Tallapragada RM, Branton A, Trivedi D, Nayak G, Jana S (2015) Characterization of physical and structural properties of aluminum carbide powder: Impact of biofield treatment. J Aeronaut Aerospace Eng 4: 142.

[34] Trivedi MK, Nayak G, Patil S, Tallapragada RM, Latiyal O, Jana $S$ (2015) Impact of biofield treatment on atomic and structural characteristics of barium titanate powder. Ind Eng Manage 4: 166.

[35] Trivedi MK, Patil S, Nayak G, Jana S, Latiyal O (2015) Influence of biofield treatment on physical, structural and spectral properties of boron nitride. J Material Sci Eng 4: 181.

[36] Trivedi MK, Nayak G, Patil S, Tallapragada RM, Latiyal O, Jana S (2015) Characterization of physical and structural properties of brass powder after biofield treatment. J Powder Metall Min 4: 134.

[37] Ladics GS (2007) Primary immune response to sheep red blood cells (SRBC) as the conventional T-cell dependent antibody response (TDAR) test. J Immunotoxicol 4: 149-152.

[38] Joharapurkar AA, Zambad SP, Wanjari MM, Umathe SN (2003) In vivo evaluation of antioxidant activity of alcoholic extract of Rubia cordifolia Linn. and its influence on ethanolinduced immunosuppression. Indian J Pharmacol 35: 232-236.

[39] Nelson DS, Mildenhall P (1967) Studies on cytophilic antibodies. 1. The production by mice of macrophage cytophilic antibodies to sheep erythrocytes: relationship to the production of other antibodies and the development of delayed-type hypersensitivity. Aust J Exp Biol Med Sci 45: 113-130.

[40] Saiki I, Tanio Y, Yamawaki M, Uemiya M, Kobayashi S, Fukuda T, Yukimasa H, Yamamura Y, Azuma I (1981) Adjuvant activities of quinonyl-N-acetyl muramyl dipeptides in mice and guinea pigs. Infect Immun 31: 114-121.

[41] Feldman BF, Zinkl JG, Jain VC. Laboratory techniques for avian hematology," in Schalm's Veterinary Hematology, (5th Edn) Lippincott Williams \& Wilkins, Toronto, Canada, 2000.

[42] Chanda S, Dave R, Kaneria M, Shukla V (2012) Acute oral toxicity of Polyalthia longifolia var. pendula leaf extract in wistar albino rats. Pharm Biol 50: 1408-1415.

[43] OECD, OECD Guideline for Testing of Chemicals, vol. 420, Organization for Economic Cooperation and Development, Paris, France, 1992. 
192 Mahendra Kumar Trivedi et al: : Immunomodulatory Activity of Biofield Energy Healing Based Herbomineral Formulation in Sprague Dawley Rats: Evidence for Humoral and Cell-Mediated Responses

[44] Sellers RS, Morton D, Michael B, Roome N, Johnson JK, Yano B, Perry R, Schafer K (2007) Society of toxicologic pathology position paper: Organ weight recommendations for toxicology studies. Toxicol Pathol 35: 751-755.

[45] Bailey SA, Zidell RH, Perry RW (2004) Relationships between organ weight and body/brain weight in the rat: What is the best analytical endpoint? Toxicol Pathol 32: 448-466.

[46] Naik SR, Gavankar C, Thakare VN (2015) Immunomodulatory activity of Withania somnifera and Curcuma longa in animal models: Modulation of cytokines functioning. Pharmacologia 6: 168-177.

[47] Nagalakshmi D, Sridhar K, Parashuramulu S (2015) Replacement of inorganic zinc with lower levels of organic zinc (zinc nicotinate) on performance, hematological and serum biochemical constituents, antioxidants status and immune responses in rats. Vet World 8: 1156-1162.
[48] Agarwal R, Diwanay S, Patki P, Patwardhan B (1999) Studies on immunomodulatory activity of Withania somnifera (ashwagandha) extracts in experimental immune inflammation. J Ethnopharmacol 67: 27-35.

[49] Ziauddin M, Phansalkar N, Patki P, Diwanay S, Patwardhan B (1996) Studies on immunomodulatory effects of a ashwagandha. J Ethnopharmacol 50: 69-76.

[50] Amresh GR, Singh PN, Rao CV (2008) Toxicological screening of traditional medicine Laghupatha (Cissampelos pareira) in experimental animals. J Ethnopharmacol 116: 454460.

[51] Clarke TC, Black LI, Stussman BJ, Barnes PM, Nahin RL (2015) Trends in the use of complementary health approaches among adults: Unites States, 2002-2012. National health statistics reports. no 79. Hyattsville, MD: National Center for Health Statistics. 